\title{
APPLICATION OF HEALTH BELIEF MODEL TO EXPLAIN SEXUAL BEHAVIOR AMONG MEN WHO HAVE SEX WITH MEN IN SURAKARTA, CENTRAL JAVA
}

\author{
LatifahNur Alifia'1), Hermanu Joebagio²),Bhisma Murti1) \\ 1)Masters Program in Public Health, UniversitasSebelasMaret \\ 2)Faculty of Social and Political Sciences, UniversitasSebelasMaret
}

\begin{abstract}
Background: The Health Belief Model (HBM) was initially developed in the 1950s. Over three decades, the model has been one of the most widely used psychosocial approaches to explaining health-related behavior including HIV/AIDS determinants. This study aimed to explain sexual behavior among men who have sex with men in Surakarta, Central Java, using HBM, with qualitative study approach.

Subjects and Method:This was a qualitative study using phenomenology approach. The study was carried out at a men who have sex with men (MSM) community group namely the Gaya Mahardhika Community (GMC), Surakarta, Central Java. The key informants included chair of the GMC and the GMC members. The supportive informants included health personnel, disease control and prevention staff from the City Health Office Surakarta, and the commission for HIV/AIDS control, Surakarta. The data were collected by in-depth interview, non-participative observation, and document review. The data were analyzed using Miles and Huberman approach.

Results:Risky sexual behaviors practiced by MSM in Surakarta included kissing, anal sex(analingus), oral sex (fellatio), and multiple partner sex. Safe sex behaviors practiced by some of them included condom use and voluntary counselling and testing (VCT) quarterly. Knowledge and perception about HIV/AIDS contributed to perceived susceptibility. Social stigma and perception about the antiretrovirus treatment (ARV) affected perceived seriousness. The MSM under study perceived HIV and sexual transmitted disease prevention effort as beneficial. The perceived barrier included discomfort of using condom. Multiple and changing sexual partners were considered normal. The cues to action for HIV/AIDS control and prevention derived from self and the community. Most of the MSM had self efficacy to apply HIV/AIDS control and prevention effort.

Conclusion: HBM can be applied to explain HIV/AIDS preventive behaviors as in this study. Perceived susceptibility, seriousness, benefit, barrier, cues to action, and self efficacy, predict HIV/AIDS related behavior among MSM.
\end{abstract}

Keywords:MSM, Health Belief Model, HIV/AIDS control and prevention

\section{Correspondence:}

LatifahNurAlifia. Masters Program in Public Health,UniversitasSebelasMaret. Jl. Ir. Sutami36A, Surakarta57126, Central Java, Indonesia.

Email: Latifahnuralifia@gmail.com. Mobile: 08562623045.

The 5 th International Conference on Public Health Best Western Premier Hotel, Solo, Indonesia, February13-14, 2019 | 167 https://doi.org/10.26911/theicph.2019.02.12 